\title{
PENINGKATAN PENDAPATAN KELUARGA MELALUI PEMANFAATAN PEKARANGAN RUMAH DENGAN MENGGUNAKAN TEKNIK VERTIKULTUR
}

\author{
Ati Kusmiati' dan Ummi Solikhah ${ }^{2}$ \\ 1,2Fakultas Pertanian, Universitas Jember \\ Email: ati.faperta@unej.ac.id, admin@faperta.unej.ac.id
}

\begin{abstract}
Along with the increasing of population led to the conversion of agricultural land into residential. Urban settlements in the Tegalgede village especially in areas caused a high density of houses and each house has a narrow yard. Until now, the yard is not used optimally so that the views of the houses in the village seem barren. One cause of the narrowness of the land and yard is limited family income. Based on the condition and situation, the problem of community are: (I) The level of education and knowledge on verticulture techniques is low, and (2) The level of education and knowledge about farming and marketing management are limited, and (3)People are not able to manage their yard optimally. Some approaches were used to solve the problem, such as socialization, counseling, and mentoring, demoplot on organic vegetable cultivation using verticulture technique, business management and marketing management. Results shows that: (I) housewife who are members of households in the group of Rose and Jasmine achieved education and new knowledge about how organic green mustard cultivation, management and cost analysis of farm business, (2) housewife has positive activities every day, (3) yard house become more green and lush, (4) Families can consume healthy organic vegetables and free of pesticides as well as save expenses, and (5) There is an additional income for housewives who sold organic green mustard (Brassica rapa) crops.
\end{abstract}

Keywords: Verticulture, organic vegetable, business management, marketing management

\section{PENDAHULUAN}

Kelurahan Tegalgede merupakan salah satu kelurahan di Kecamatan Sumbersari Kabupaten Jember yang berjarak sekitar $2 \mathrm{~km}$ dari kampus UNEJ. Jumlah penduduknya pada tahun 2010 sebesar 8.457 orang yang terdiri dari penduduk laki-laki sebesar 4.108 orang dan penduduk wanita sebesar 4.349 orang. Total luas wilayah Kelurahan Tegalgede sebesar 188,4 Ha. Luas wilayah pemukiman sebesar $80,2 \mathrm{Ha} / \mathrm{m} 2$ atau $42,6 \%$ dari total wilayah, luas pekarangan $41 \mathrm{Ha} / \mathrm{m} 2$ atau $21,8 \%$ dari total wilayah dan persawahan sebasar $8,2 \mathrm{Ha} / \mathrm{m} 2$ atau $4,3 \%$ dari total wilayah.

Pada awalnya lahan pertanian berupa sawah dan tegalan yang dimiliki Kelurahan Tegalgede cukup luas. Namun, seiring dengan semakin bertambahnya jumlah penduduk di Kabupaten Jember menyebabkan lahan pertanian tersebut beralih fungsi menjadi pemukiman penduduk. $\mathrm{Hal}$ ini terlihat dari data kelurahan Tegalgede bahwa prosentase wilayah pemukiman sebesar 42,6\%. Pada akhirnya, produksi produk-produk pertanian di Kelurahan Tegalgede pun mengalami penurunan dari tahun ke tahun. Padahal kebutuhan pangan yang diperoleh dari produk-produk pertanian selalu mengalami peningkatan.

Kelurahan Tegalgede terbagi menjadi tiga lingkungan yaitu Panji, Krajan Barat dan Krajan Timur. Lingkungan Panji termasuk wilayah yang paling padat pemukiman. Sedangkan lingkungan Krajan Timur dan Barat masih memiliki areal pertanian. 
Sebagian besar rumah yang ditempati penduduk Tegalgede khususnya lingkungan Panji memiliki luas pekarangan yang relatif sempit dan jarak antar rumah saling berdekatan, terutama rumah-rumah yang berada di daerah perkampungan. Pada akhirnya mereka tidak dapat menanam tanaman untuk menghijaukan pekarangan rumahnya. Salah satu penyebab sempitnya rumah dan pekarangan yang dimiliki adalah rendahnya pendapatan yang diperoleh keluarga. Sebagian besar mata pencaharian penduduk tersebut adalah kuli, tukang bangunan, tukang becak, dan pekerja serabutan. Pendapatan yang diperoleh tersebut masih belum mampu digunakan untuk menutupi kebutuhan sekolah anaknya sampai SMU meskipun para istri telah bekerja sebagai pembantu rumah tangga, buruh gudang tembakau dan membuka warung peracangan.

Lahan pekarangan yang sempit sebenarnya masih dapat dimanfaatkan untuk kegiatan budidaya. Salah satu teknik budidaya yang dapat diterapkan pada lahan yang sempit adalah teknik Vertikultur. Vertikultur dapat diartikan sebagai teknik budidaya tanaman secara vertikal sehingga penanaman dilakukan secara bertingkat. Teknik budidaya ini tidak memerlukan lahan yang luas, bahkan dapat dilakukan pada rumah yang tidak memiliki halaman sekalipun. Pemanfaatan teknik vertikultur ini memungkinkan untuk berkebun dengan memanfaatkan tempat secara efisien. Secara estetika, taman vertikultur berguna sebagai penutup pemandangan yang tidak menyenangkan atau sebagai latar belakang yang menyuguhkan pemandangan yang indah dengan berbagai warna. Bercocok tanam secara vertikultur sebenarnya tidak berbeda dengan bercocok tanam di kebun maupun di ladang. Mungkin sekilas bercocok tanam secara vertikultur terlihat rumit, tetapi sebenarnya sangat sederhana. Tingkat kesulitannya tergantung dari model yang digunakan. Model yang sederhana, mudah diikuti dan dipraktekan. Bahkan bahan-bahan yang digunakan mudah ditemukan, sehingga dapat diterapkan oleh ibu-ibu rumah tangga.

Jenis-jenis tanaman yang dibudidayakan biasanya adalah tanaman yang memiliki nilai ekonomi tinggi, berumur pendek atau tanaman semusim khususnya sayuran (seperti seledri, caisism, pack-choy, baby kalian, dan selada), dan memiliki sistem perakaran yang tidak terlalu luas. Bahanbahan yang digunakan dapat berupa kaleng bekas, pot, botol dan gelas plastik, bambu dan pipa PVC.

Menurut Damastuti, Anya P (1996), Sistem pertanian vertikultur adalah sistem budi daya pertanian yang dilakukan secara vertikal atau bertingkat. Sistem ini cocok diterapkan pada lahan sempit atau di pemukiman yang padat penduduknya. Sistem ini dapat menjadi solusi kesulitan mencari lahan pertanian yang tergusur oleh perumahan dan industri. Kelebihan sistem pertanian vertikultur sebagai berikut: (1) efisiensi penggunaan lahan karena yang ditanam jumlahnya lebih banyak dibandingkan sistem konvensional, (2) penghematan pemakaian pupuk dan pestisida, (3) kemungkinan tumbuhnya rumput dan gulma lebih kecil, (4) dapat dipindahkan dengan mudah karena tanaman diletakkan dalam wadah tertentu, (5) mempermudah monitoring/pemeliharaan tanaman, dan (6) adanya atap plastik memberikan keuntungan (a) mencegah kerusakan karena hujan, (b) menghemat biaya penyiraman karena atap plastik mengurangi penguapan. Kekurangannya adalah (1) rawan terhadap serangan jamur, karena kelembaban udara yang tinggi akibat tingginya populasi tanaman adanya atap plastik, (2) investasi awal cukup tinggi, (3) sistem penyiraman harus kontinyu, dan diperlukan beberapa peralatan tambahan, misalnya tangga sebagai alat bantu penyiraman.

Jenis tanaman yang dapat ditanam dengan sistem ini sangat banyak, misalnya a) tanaman sayur semusim (sawi,selada, kubis, wortel, tomat, terong, cabai dan lain-lainnya), b) tanaman bunga seperti anggrek, mawar, melati, azalea, kembang sepatu, dll; dan c) tanaman obat-obatan yang sekulen. Terdapat 
tiga aspek yang harus dipersiapkan dalam budidaya tanaman organik secara vertikultur, yaitu: (1) Pembuatan rak vertikultur, (2) Penyiapan dan penggunaan pupuk organic, (3) Penanaman dan pemeliharaan. Pelaksanaan vertikultur dapat menggunakan bangunan khusus (modifikasi dari sistem green house) maupun tanpa bangunan khusus, misalnya di pot gantung dan penempelan di tembok-tembok. Wadah tanaman sebaiknya disesuaikan dengan bahan yang banyak tersedia di pasar lokal. Bahan yang dapat digunakan, misalnya kayu, bambu, pipa paralon, pot, kantong plastik dan gerabah. Bentuk bangunan dapat dimodifikasi menurut kreativitas dan lahan yang tersedia (Sastro, 2010).

Penanaman bibit tanaman untuk sistem vertikultur ini sebenarnya tidak jauh berbeda dengan cara konvensional. Sebelum menanam, kita harus mengetahui karakteristik tanaman yang akan ditanam. Apakah bibit tanaman itu mesti disemai dulu atau langsung ditanam. Tujuan penyemaian ini diharapkan agar bibit tanaman seragam dalam hal bentuk maupun umur dapat seragam satu sama lain.

Benih yang perlu disemai antara lain selada, cabai, dan tomat. Sedangkan bibit yang dapat langsung ditanam misalnya kangkung dan bayam. Untuk proses persemaian ini tidak berbeda dengan cara konvensional. Kita dapat menyiapkan wadah, misalnya nampan plastik/kotak kayu. Campurkan kompos dan arang sekam dengan perbandingan $1: 1$, aduk hingga rata kemudian masukkan dalam wadah yang telah disiapkan. Taburkan benih secara merata, kemudian timbun dengan pasir halus. Penyiraman dilakukan secara rutin, sekali setiap hari. Gunakan semprotan/hand sprayer yang berlubang kecil agar air siraman yang keluar tidak terlalu deras.

Untuk mengelola bibit yang langsung ditanam serta bibit hasil persemaian yang telah siap tanam, siapkan dahulu media tanam yang terdiri dari tanah, pasir halus dan kompos dengan perbandingan 2:1:1. Media tanam kemudian dimasukkan ke dalam pot atau wadah lain yang telah disiapkan.
Tebarkan 3-5 benih yang langsung ditanam ke dalam pot/wadah. Untuk bibit hasil persemaian, pemindahan ke rak baru dilakukan jika telah tumbuh 3-4 helai daun (BPTP Jawa Tengah, 2006).

Teknik vertikultur ini sama sekali masih belum diterapkan oleh ibu-ibu rumah tangga di Kelurahan Tegalgede. Hal ini dikarenakan para ibu rumah tangga belum mengetahui teknik atau cara budidaya dengan menggunakan teknik vertikultur ini. Aplikasi teknik vertikutur sangat bermanfaat bagi keluarga, antara lain dengan menanam sayuran di pekarangan maka pengeluaran rumah tangga untuk konsumsi sayuran dapat dikurangi dan sayuran yang dipanen dapat dijual sehingga dapat menambah pendapatan keluarga.

Berdasarkan kondisi dan situasi tersebut maka pemberian pelatihan dan demoplot melalui penerapan Iptek penggunaan teknik vertikultur pada budidaya sayuran sangat diperlukan untuk meningkatkan pengetahuan dan ketrampilan ibu rumah tangga yang pada gilarannya nanti akan meningkatkan pendapatan keluarga. Selain itu, perlu dilakukan pula penyuluhan dan pendampingan mengenai manajemen usahatani dan pemasaran hasil sayuran yang telah dibudidayakan.

Berdasarkan kondisi dan situasi tersebut prioritas permasalahan masyarakat mitra sebagai berikut:

1. Tingkat pendidikan dan pengetahuan tentang teknik vertikultur pada budidaya sayuran sangat terbatas.

2. Tingkat pendidikan dan pengetahuan tentang manajamen usahatani dan pemasaran sangat terbatas.

3. Masyarakat Kelurahan Tegalgede memiliki lahan pekarangan yang sempit dan sama sekali belum dimanfaatkan secara optimal sehingga pendapatan keluarga belum dapat ditingkatkan

\section{METODE}

Pelaksanaan penyuluhan dan praktek budidaya tanaman sawi organik dengan 
menggunakan teknik vertikultur, manajemen usaha dan analisis biaya produksi sampai dengan pemasaran dilakukan sejak bulan Juli sampai Oktober 2013. Pelaksanaan penyuluhan dan praktek tersebut dilakukan di JL. Tawangmangu V Kelurahan Tegalgede Kecamatan Sumbersari Kabupaten Jember. Khalayak sasaran kegiatan penyuluhan dan praktek pemanfaatan lahan pekarangan dengan menggunakan teknik vertikultur adalah ibu-ibu rumah tangga yang tergabung dalam kelompok mawar dan melati. Masingmasing kelompok terdiri dari 1 ketua dan 10 anggota.

Untuk mewujudkan pekarangan yang hijau dan meningkatkan pendapatan keluarga melalui aplikasi teknik vertikultur pada tanaman sayuran maka perlu disusun metode pendekatan sehingga program ini dapat berjalan dengan baik. Langkah-langkah yang dapat dilakukan sebagai berikut:

1. Untuk optimalisasi pemanfaatan lahan pekarangan dengan menggunakan teknik vertikultur dibentuk 2 kelompok ibu rumah tangga dengan masing-masing 1 kader dan 10 anggota.

2. Sosialisasi tentang aplikasi vertikultur tanaman sayuran, manajemen usahatani dan pemasaran dengan menyebarkan booklet kepada kelompok.

3. Penyuluhan dan pelatihan teknik vertikultur, manajemen usahatani dan pemasaran tanaman sayuran yang dilakukan di mushola JL.Tawangmangu Gang V.

4. Demoplot dan aplikasi vertikultur dengan membuat satu contoh budidaya sayuran dengan teknik vertikulur dan semua anggota kelompok turut mempraktekkan aplikasi tersebut di setiap pekarangan rumah masing-masing

5. Pendampingan melalui pemantauan proses budidaya dan aplikasi manajemen usahatani serta mengupayakan proses pemasaran hasil panen sayuran dalam kemasan yang siap jual.

Adapun bahan, alat dan prosedur yang dugunakan untuk melakukan budidaya sawi organik sebagai berikut:
Alat yang digunakan adalah bamboo, paku, pipa PVC, sprayer, dan bak pembenihan. Adapun bahan yang digunakan adalah kompos, tanah, pasir, pot, polibag, benih sawi, dan air.

Prosedur:

1. Buat rak bambu yang tersusun secara vertikal dengan kapasitas 80 polibag. Atau dapat juga dengan melubangi pipa PVC, dapat dilihat pada gambar berikut:

2. Siapkan bak pembenihan yang telah berisi media tanam yang terdiri dari pasir, tanah, kompos dengan perbandingan $1: 1: 1$. Tebarkan benih diatasnya

3. Lakukan penyiraman rutin dengan menggunakan sprayer setiap pagi dan sore, usahakan media selalu lembab

4. Setelah benih berumur kurang lebih antara 10 - 14 hari dan daunnya menunjukkan daun sejati minimal dua lembar, pindahlah benih yang sudah siap tanam tersebut ke polibag yang sudah terisi media tanam.

5. Lakukan pemeliharaan dengan menyiram tanaman sawi setiap hari pada pagi dan sore hari. Pilihlah tempat terbuka sehingga tanaman sawi memperoleh cahaya matahari yang cukup.

6. Lakukan penyiangan apabila ada rumput yang mengganggu dan mengecek setiap hari kondisi tanaman agar apabila ada hama seperti ulat dapat segera terdeteksi. Apabila ada ulat maka ulat tersebut secara manual langsung diambil dengan tangan tanpa harus memberikan pestisida.

7. Setelah tanaman sawi berumur kurang lebih satu bulan, maka sawi tersebut siap dipanen.

8. Hasil panen sawi dibersihkan dari tanah yang menempel kemudian dibungkus dengan kertas dan plastic agar tanaman sawi terjaga kesegarannya

9. Sawi siap dipasarkan

\section{HASIL DAN PEMBAHASAN}
A. Peningkatan
Pendidikan
dan
Pengetahuan tentang Cara Budidaya, Manajemen Usaha dan Manajemen Pemasaran Tanaman Organik 
Kelurahan Tegalgede merupakan salah satu wilayah yang berada di pinggiran kota Kabupaten Jember. Jarak kelurahan Teglagede dengan Universitas Jember sekitar dua kilometer. Namun, kondisi pendidikan masyarakat kelurahan Tegalgede khususnya di sekitar Jalan Tawangmangu gang $\mathrm{V}$ belum terlalu tinggi. Masih ada juga penduduk gang tersebut yang buta huruf. Selain itu, rata-rata tingkat pendidikannya maksimal SMA, bahkan ada yang tidak tamat SMP. Hal ini menunjukkan bahwa jarak yang dekat dari pendidikian tinggi tidak menjamin masyarakatnya tergerak untuk meneruskan ke jenjang pendidikan yang lebih tinggi.

Ketidakterjangkauan masyarakat ke jenjang pendidikian tinggi disebabkan karena keterbatasan pendapatan yang dimiliki oleh masyarakat khususnya masyarakat di JL. Tawangmangu $\mathrm{V}$ jember dan rendahnya kesadaran orangtua untuk menyekolahkan anaknya ke perguruan tinggi. Sebagian besar masyarakatnya bekerja sebagai kuli, tukang bangunan, tukang becak, pekerja serabutan, satpam, pedagang kambing, petani, peternak, buruh tani, pelayan toko, membuka toko peracangan dan wirausaha lainnya. Oleh karenanya, penting sekali bagi penduduk tersebut untuk meningkatkan pendapatan dan kesadaran orang tua tentang pendidikan.

Salah satu upaya yang dapat dilakukan untuk meningkatkan pendapatan keluarga adalah dengan memanfaatkan lahan pekarangan yang dimiliki. Sebagian besar rumah yang ditempati penduduk Tegalgede khususnya lingkungan Panji memiliki luas pekarangan yang relatif sempit dan jarak antar rumah saling berdekatan, terutama rumah-rumah yang berada di daerah perkampungan. Pada akhirnya mereka tidak dapat menanam tanaman untuk menghijaukan pekarangan rumahnya.

Lahan pekarangan yang sempit sebenarnya masih dapat dimanfaatkan untuk kegiatan budidaya. Salah satu teknik budidaya yang dapat diterapkan pada lahan yang sempit adalah teknik Vertikultur. Vertikultur dapat diartikan sebagai teknik budidaya tanaman secara vertikal sehingga penanaman dilakukan secara bertingkat. Teknik budidaya ini tidak memerlukan lahan yang luas, bahkan dapat dilakukan pada rumah yang tidak memiliki halaman sekalipun.

Pemanfaatan teknik vertikultur ini memungkinkan untuk berkebun dengan memanfaatkan tempat secara efisien. Secara estetika, taman vertikultur berguna sebagai penutup pemandangan yang tidak menyenangkan atau sebagai latar belakang yang menyuguhkan pemandangan yang indah dengan berbagai warna. Bercocok tanam secara vertikultur sebenarnya tidak berbeda dengan bercocok tanam di kebun maupun di ladang. Mungkin sekilas bercocok tanam secara vertikultur terlihat rumit, tetapi sebenarnya sangat sederhana. Tingkat kesulitannya tergantung dari model yang digunakan.

Model vertikultur yang digunakan ada dua macam yaitu rak bambu dengan tinggi kurang lebih dua meter dan pipa PVC dengan tinggi kurang lebih $130 \mathrm{~cm}$. Rak bambu yang telah dibuat mampu memuat 80 polibag ukuran sedang dimana setiap polibag dapat diisi dengan 2-3 batang tanaman sawi. Sedangkan pipa PVC berisi 20 (dua puluh) lubang berarti berisi 20 tanaman sawi. Bagian bawah pipa diberi pot yang berisi tanaman sawi sehingga total tanaman yang dapat di tanam pada media PVC adalah 25 batang tanaman sawi.

Ibu-ibu rumah tangga yang tergabung dalam kelompok mawar dan melati memperoleh media yang sudah dibuatkan oleh tim pelaksana program IbM LPM Unej. Tim pelaksana dengan dibantu oleh pekerja yang membuat rak bambu dan PVC memperagakan proses pembuatannya. Dengan demikian, apabila di kemudian hari model vertikultur yang telah diberikan rusak maka ibu-ibu rumah tangga dapat membuatnya sendiri. Proses pembuatannya sangat mudah dan bahan-bahan seperti bambu dan pipa PVC mudah dicari.

Pada awalnya, kelompok mawar dan melati diundang oleh tim pelaksana untuk mengikuti kegiatan sosialisasi program IbM sekaligus penyuluhan pertama tentang budidaya 
tanaman sayuran. Pada saat penyuluhan tersebut, ibu-ibu rumah tangga dikenalkan dengan istilah teknik vertikultur, cara pembuatan model vertikultur, dan berbagai tanaman sayuran yang dapat dibudidayakan dengan teknik vertikultur. Jenis-jenis tanaman yang dibudidayakan biasanya adalah tanaman yang memiliki nilai ekonomi tinggi, berumur pendek atau tanaman semusim khususnya sayuran (seperti seledri, caisism, pack-choy, baby kalian, dan selada), dan memiliki sistem perakaran yang tidak terlalu luas.

Hasil kesepakatan bersama pada saat penyuluhan tersebut memutuskan bahwa tanaman yang akan dibudidayakan adalah tanaman sawi organik karena cara perawatan tanaman sawi sangat mudah yaitu cukup dilakukan penyiraman setiap hari, mendapatkan cahaya matahari yang cukup dan tanpa pestisida. Masing-masing lbu-lbu rumah tangga memperoleh benih sawi yang nantinya akan diaplikasikan sendiri di rumah masing-masing.

Kegiatan penyuluhan tersebut dilanjutkan dengan demonstrasi penyebaran benih yang dilakukan secara bersama-sama antara tim pelaksana IbM dan peserta penyuluhan. Benih disebar pada bak pembenihan yang telah diisi media berupa tanah, pasir dan kompos dengan perbandingan $1: 1: 1$. Media tersebut disiram dengan air dan selalu diusahakan lembab setiap hari. Pembenihan berlangsung selama 10 sampai 14 hari. Sepuluh sampai empat belas hari setelah penyuluhan, benih yang sudah disebar sudah memiliki minimal dua daun sejati. Bibit ini dipindah ke polibag yang sudah diisi oleh media tanam. Setiap hari ibu-ibu rumah tangga harus menyiram tanaman sawi tersebut. Hama yang sering muncul adalah ulat, belalang, ayam dan kutu di dalam tanah. Hama tersebut harus segera diambil secara manual karena ulat tersebut cepat sekali menghabiskan daun-daun sawi. Untuk menghindari daun sawi yang dimakan ayam maka disekeliling tanaman diberi waring.

Peserta penyuluhan sangat antusias mendengarkan materi penyuluhan karena teknik vertikultur dan budidaya organik merupakan pengetahuan baru bagi ibu-ibu rumah tangga. Sebelumnya, ibu-ibu rumah tangga belum tahu istilah vertikultur dan organik. Para ibu-ibu rumah tangga, menganggap bahwa racun/pestisida harus selalu disemprotkan ketika tanaman dihinggapi ulat atau hama lainnya. Penyuluh juga menjelaskan kelebihan teknik vertikultur tanaman sayuran dan tanaman organik. Kelebihan teknik vertikultur tanaman sayuran antara lain:

1. lahan pekarangan yang sempit masih dapat digunakan untuk kegiatan budidaya,

2. adanya tanaman di pekarangan rumah akan membuat rumah menjadi asri, sejuk dan pemandangan pekarangan menjadi lebih indah,

3. tanaman sayuran yang dipanen dapat dikonsumsi sendiri,

4. kelebihan hasil panen sayuran dapat dijual sehingga menambah pendapatan keluarga.

Kelebihan tanaman organik antara lain:

1. sehat karena tidak mengandung zat-zat kimia,

2. sayuran lebih segar dan awet disimpan lama dalam kulkas,

3. sayuran organik lebih renyah dan manis.

\section{B. Peningkatan Pendapatan Melalui Pemanfaatan Pekarangan dengan Menggunakan Teknik Vertikultur}

Tanaman sawi yang sudah berumur kurang lebih satu bulan dapat segera dipanen. Budidaya sawi dikerjakan selama dua kali musim tanam yaitu terhitung sejak bulan Juli sampai Oktober 2013. Tim pelaksana IbM juga ikut memberikan demoplot budidaya sawi organik. Ibu-ibu rumah tangga mengalami banyak permasalahan selama melakukan perawatan tanaman sawi di pekarangannya. Beberapa ibu ada yang kurang berhasil dalam budidaya. Ketidakberhasilan proses budidaya sawi organik ditemukan ketika Tim pelaksana IbM melakukan monitoring budidaya sawi organik. Banyak permasalahan yang dihadapi ibu rumah tangga seputar proses budidaya sawi organik. Permasalahan-permasalahan tersebut muncul karena: 
1. Pada waktu proses pembenihan, media tanam yang digunakan terlalu basah sehingga benih membusuk dan tidak tumbuh,

2. Tempat budidaya sawi kurang terkena cahaya matahari langsung sehingga tanaman sawi tidak tumbuh optimal,

3. Polibag yang berisi bibit sawi langsung dipindah ke rak bambu sehingga tanaman kurang dapat tumbuh optimal karena perakarannya belum kuat,

4. Benih langsung disebar di pilibag atau pipa PVC tanpa melalui proses pembenihan terlebih dahulu

5. Tanaman sawi yang mulai berdaun dimakan oleh ayam dan tikus

6. Tanaman sawi tumbuh dengan lambat dan kurus

Setelah monitoring dilakukan maka Tim pelaksana lbM mengumpulkan anggota kelompok pada acara penyuluhan yang kedua sekaligus panen perdana pada musim tanam pertama. Pada saat penyuluhan tersebut, masing-masing anggota saling berbagi pengalaman proses budidaya organik. Penyuluh memberikan masukan terkait dengan permasalahan yang dihadapi ibu-ibu rumah tangga. Solusi yang diambil untuk mengatasi permasalahan tersebut antara lain:

1. Pada akhirnya ibu-ibu mengetahui contoh kelembaban media yang tepat untuk pembenihan. Hal ini didasarkan pengalaman uji coba sebelumnya dan melihat pembenihan pada demoplot yang disiapkan dan melihat hasil ibu-ibu lainnya

2. Tempat budidaya dipilih pada tempat yang terkena cahaya matahari secara langsung dan secara rutin harus menyiram tanaman sawi setiap hari

1. Memindah polibag ke atas rak bambu ketika tanaman sawi sudah berumur lebih dari lima belas hari

2. Benih harus ditebar di bak pembenihan atau bekas gelas aqua atau tempat lainnnya yang memungkinkan asalkan bukan langsung di pipa PVC atau langsung di polibag tanpa dipindah lagi

3. Sekeliling rak bambu dan pipa PVC diberi pagar berupa kayu atau waring
4. Media tanamn diberi pupuk kandang sehingga tanaman sawi lebih besar dan sehat

Sebagian besar hasil panen sawi organik para ibu-ibu rumah tangga dikonsumsi sendiri dan dibagikan ke saudaranya. Namun, ada juga hasil panennya yang dijual karena hasil panennya melimpah. Pada awalnya, ibu tersebut menjual ke warung dekat rumah dengan harga jual yang sama dengan sawi non organik. Pada akhirnya tim pelaksana IbM mencarikan konsumen yang bersedia membeli dengan harga yang pantas untuk sawi organik. Segmen konsumen organik adalah orang yang memiliki pendapatan menengah ke atas dimana orang-orang tersebut memahami keuntungan mengkonsumsi sayuran organik dan perduli tentang kesehatannya. Harga sawi organik dua kali lipat lebih mahal dari sawi non organik. Saat ini, harga sawi non organik sebesar Rp 500,00 per ikat. Sawi organik non organik yang dihasilkan ibu-ibu rumah tangga di Kelurahan Tegalgede dihargai Rp 1.000,00 per ikat. Salah satu anggota kelompok yang bernama lbu Toyani berhasil menjual 52 ikat sawi organik. Ibu rumah tangga yang tergabung dalam kelompok berhasil menikmati uang dari hasil jerih payah memelihara tanaman sawinya. Hal ini akan memacu semangat para ibu-ibu yang lainnya yang masih belum telaten dalam merawat sawi organik. Pada akhirnya nanti, jika semangat, ketelatenan dan kesabaran ibu-ibu yang tergabung dalam kelompok mawar dn melati maka mimpi bersama untuk menjadikan tempat tinggalnya menjadi "Gang Organik" dapat menjadi kenyataan dan pendapatan masyarakatnya semakin bertambah.

\section{KESIMPULAN}

Berdasarkan hasil dan pembahasan dapat diambil beberapa kesimpulan sebagai berikut:

1. Ibu-lbu rumah tangga yang tergabung dalam kelompok mawar dan melati memperloleh pendidikan dan pengetahuan baru mengenai cara budidaya sawi 
organik, manajemen usaha dan analisis biaya usahatani.

2. Ibu rumah tangga memiliki aktifitas positif yang rutin dilakukan setiap hari

3. Pekarangan rumah JL. Tawangmangu V menjadi lebih hijau dan asri

4. Keluarga dapat mengkonsumsi sayuran organik yang sehat karena terbebas dari pestisida sekaligus dapat menghemat pengeluaran

5. Ada tambahan pendapatan bagi para ibu rumah tangga yang berhasil menjual hasil panen sawi organiknya.

\section{DAFTAR PUSTAKA}

Assauri, S. 2004. Manajemen Pemasaran. PT Grafindo Persada. Jakarta.

BPTP Jawa Tengah. 2006. Vertikultur. BPTP. Jawa

Tengah.

Hernanto, Fadholi, 1995. Ilmu Usahatani. Penebar Swadaya. Jakarta.

Sastro, Yudi, 2010. Budidaya Tanaman Organik Secara Vertikultur. BP-TP Jakarta. Jakarta.

Sutarminingsih, C. 2003. Vertikultur Pola Bertanam Secara Vertikal. Kanisius. Yogyakarta. 